\title{
DEVELOPING AN EFFECTIVE WORKFLOW MODULE FOR PRODUCTIVITY ANALYSIS USING STATISTICAL METHODS IN VARIOUS CONSTRUCTION SITES
}

\author{
N.Indulekha ${ }^{1}$, S.Anandh ${ }^{2}$ \\ ${ }^{1}$ Student, Construction engineering and management, SRM University, Tamil Nadu, India \\ ${ }^{2}$ Assistant Professor, Construction engineering and management, SRM University, Tamil Nadu, India
}

\begin{abstract}
Productivity plays a vital role in the success of any construction project. Productivity improvements leads to the higher cost saving with minimal investment. The main objective of the study is to find out the factors affecting construction productivity. The various types of risks were identified and based on the risk factors that affects construction productivity a questionnaire was framed A questionnaire survey was carried out in the southern part of India. The questionnaire is distributed to various civil engineers, contractors, site engineers, planning engineers and total of 53 respondents were obtained. The analysis is carried out using Statistical Product and Service Solutions (SPSS). From the analysis mean and their respective ranks were found out, based on which the conclusions are made.
\end{abstract}

Keywords: Productivity, Questionnaire, risk, questionnaire survey

\section{INTRODUCTION}

Construction industry plays a vital role in developing the country's infrastructure ultimately improving the country's economical status. Number of planners, engineers and consultants are involved throughout the completion of any construction project. Systematic planning leads to the successful implementation of the plan thus leading to the successful completion of the project. Productivity plays a very important role in any construction site. Thus improving productivity by applying various modern methods leads to the project success which saves both money and time. Effective utilization of the 4M's namely men, material, machinery, money leads to the success of any construction project .Productivity in general is the ratio between the output and the input. It is the key factor for the project's success. It can be improved by proper implementation and tracking of works that is being carried out in the construction site. The project standards are rated based on productivity. The overall analysis of productivity gives an idea about the delays and factors of delay that affects the construction activities which leads to the cost overrun and time over run. The delay can be minimized by proper scheduling of activities using and subsequently scheduling can also be done if there is any error in scheduling of activities , thereby improving productivity.

Productivity plays a vital role both in micro and macro levels. The construction cost can be minimized by improving the productivity ultimately completing the construction project within the stipulated time. The software by name SPSS is are used, the construction delays are also reduced by this study.

\section{LITERATURE REIVIEW}

Saleh al Hadi Jumi, Abdelnaser Omran, Abdul Hamid Kadhir Pakir, (Nov 2009) has found that delays can lead to many negative effects such as lawsuits betwwen owners and contractors, increased cost, oss of productivity and revenue and termination. Even though various studiees have been taken into acccount, these studies discuss only the common and general causes of delays in construction project. Thus a comprehensive study on these delays is essential. The study leads to focus on specific causes of delaying like insufficient cordination and effective communication.

Jarek Hegazy, Mohammad Said; Moustafa Kassab(2011) recorded all progress events, including rework and calculate the expected project delay. Analyse the project delay to identifying the number of days attributed each parties action.

Per-Eeick Josephson ; Bengt Lasson ; Hengli (April 2002)says that rework has become an endemic feature of the procurement process in construction that invariably leads to time and cost over runs in projects in order to improve the performance, it is necessary to identify the causes and cost of construction networ

Oko John Aneh, Emeka Emmanuel, Oregboh (Nov 2011) says that the history of construction industry world wide is full of projects that were completed with significant time and cost over runs. In an atempt to reverse this trend, this study aims at establishing the relationship between time over run and labour productivity on construction site in Lagos. 
Polycorp Olabu Alumbugu, Saidu, Ibrahim, Abdullaih Sa Adu Gulma (Vol 6 no 4 2014) Wasiuadenran Ola-Awo analyse the relationship betwwen workin height and productivity of masonary worker on construction site by investigating two project site. Data were also gatherd by observing work activity on site.

\section{FACTORS AFFECTING PRODUCTIVITY IN}

\section{CONSTRUCTION SITE}

- Lack of material

- Lack of equipment

- Absentiseem

- Supervision delays

- Delays in clients decision

- Labour personal conflict

- Shortage of unskilled labour

- Uncertain productivity of men

- Improper time management assistance

- Poor management assistance

- Inadequate scheduling process

- Price fluctuation in the market

- Inadequate site investigation

- Inspection delay

- Unrealistic time and cost schedule

- Incomplete design

- Errors in choosing the construction method

- Changes in monsoon cycle

\section{QUESTIONNAIRE ANALYSIS}

The data collected from the from all 53 respondents are fed into the SPSS software and their respective mean, rank, overall mean and overall rank are obtained. The questions in the questionnaire survey are framed based on the risk factors which affect the construction productivity.

\subsection{Questionnaire details}

The tables given below are the results obtained from the SPSS analysis. The questionnaire are rated on laggard scale is given in the table 4.1. Ranking is based on extent of agreeing on a scale of 1-5 as follows.

\begin{tabular}{|l|l|l|l|l|}
\hline $\begin{array}{l}\text { Strongly } \\
\text { disagree }\end{array}$ & Disagree & Neutral & Agree & $\begin{array}{l}\text { Strongly } \\
\text { disagree }\end{array}$ \\
\hline 1 & 2 & 3 & 4 & 5 \\
\hline
\end{tabular}

Table 4.2 are the results obtained from the analysis which falls under technical risk.
Table 4.2 Input data of technical risk

\begin{tabular}{|c|c|c|c|}
\hline Q no & Question & Mean & Rank \\
\hline 1 & $\begin{array}{l}\text { Inadequate site } \\
\text { investigation }\end{array}$ & 4.30 & 2 \\
\hline 2 & Incomplete design & 4.55 & 1 \\
\hline 3 & $\begin{array}{l}\text { Uncertainty over the } \\
\text { availability of construction } \\
\text { materials }\end{array}$ & 4.1 & 5 \\
\hline 4 & $\begin{array}{l}\text { Lack of supervision } \\
\text { of site engineer }\end{array}$ & 4.125 & 4 \\
\hline 5 & $\begin{array}{l}\text { Error in choosing } \\
\text { construction method }\end{array}$ & 3.975 & 9 \\
\hline 6 & $\begin{array}{l}\text { Inadequate specification } \\
\text { and standards } \\
\text { by the architect }\end{array}$ & 4.075 & 6 \\
\hline 7 & $\begin{array}{l}\text { Poor communication } \\
\text { between the site } \\
\text { engineer and labours }\end{array}$ & 4.250 & 3 \\
\hline 8 & $\begin{array}{l}\text { Not completely } \\
\text { understanding the } \\
\text { clients requirements }\end{array}$ & 3.975 & 10 \\
\hline 9 & $\begin{array}{l}\text { Inspection delay by the } \\
\text { Planning engineer }\end{array}$ & 4.0 & 8 \\
\hline 10 & Shift work & 4.055 & 7 \\
\hline
\end{tabular}

Table 4.3 are the results obtained from the analysis which falls management risk

Table 4.3 Input data of management risk

\begin{tabular}{|c|l|c|c|}
\hline Q no & \multicolumn{1}{|c|}{ Question } & Mean & Rank \\
\hline 1 & Delay in clients decision & 4.2 & 3 \\
\hline 2 & $\begin{array}{l}\text { Stoppages due } \\
\text { to dispute between } \\
\text { owner and contractor }\end{array}$ & 4.27 & 1 \\
\hline 3 & $\begin{array}{l}\text { Labour personal } \\
\text { conflict }\end{array}$ & 3.85 & 8 \\
\hline 5 & $\begin{array}{l}\text { Shortage of unskilled } \\
\text { labor }\end{array}$ & 3.9 & 7 \\
\hline 6 & $\begin{array}{l}\text { Time management } \\
\text { of labours }\end{array}$ & 3.92 & 6 \\
\hline 7 & $\begin{array}{l}\text { Poor project } \\
\text { management assistance } \\
\text { construction crew in } \\
\text { production objectives }\end{array}$ & 3.55 & 11 \\
\hline 8 & $\begin{array}{l}\text { Time management } \\
\text { of equipments }\end{array}$ & 3.85 & 9 \\
\hline 9 & $\begin{array}{l}\text { Uncertain productivity } \\
\text { of machinery }\end{array}$ & 3.67 & 10 \\
\hline 10 & $\begin{array}{l}\text { Inadequate program } \\
\text { scheduling }\end{array}$ & 4.3 & 2 \\
\hline 11 & $\begin{array}{l}\text { Uncertain productivity } \\
\text { of men }\end{array}$ & 4.10 & 5 \\
\hline & & \\
\hline
\end{tabular}


Table 4.4 are the results obtained from the analysis which falls financial risk.

Table 4.4 Input data of financial risk

\begin{tabular}{|c|c|c|c|}
\hline Q no & Question & Mean & Rank \\
\hline 1 & $\begin{array}{l}\text { Standard wage } \\
\text { schemes in firm }\end{array}$ & 4.24 & 1 \\
\hline 2 & $\begin{array}{l}\text { Price fluctuation } \\
\text { in the market }\end{array}$ & 4.02 & 4 \\
\hline 3 & $\begin{array}{l}\text { Financial difficulties } \\
\text { of owners }\end{array}$ & 4.22 & 2 \\
\hline 4 & $\begin{array}{l}\text { Financial difficulties } \\
\text { of contractors }\end{array}$ & 3.65 & 10 \\
\hline 5 & $\begin{array}{l}\text { Additional works added } \\
\text { during the course of } \\
\text { construction process }\end{array}$ & 4.12 & 3 \\
\hline 6 & $\begin{array}{l}\text { Delays in payment to } \\
\text { the members of the } \\
\text { construction projects }\end{array}$ & 3.70 & 9 \\
\hline 7 & Inflation in the market & 3.97 & 6 \\
\hline 8 & $\begin{array}{l}\text { Fluctuation in foreign } \\
\text { exchange }\end{array}$ & 3.82 & 8 \\
\hline 9 & $\begin{array}{l}\text { Effect of availability of } \\
\text { finance from } \\
\text { contractor side }\end{array}$ & 3.95 & 7 \\
\hline 10 & $\begin{array}{l}\text { Effect of availability } \\
\text { of finance from owner side }\end{array}$ & 3.97 & 5 \\
\hline
\end{tabular}

Table 4.5 are the results obtained from the analysis which falls environmental risk.

Table 4.5 input data of Environmental risk

\begin{tabular}{|c|l|c|c|}
\hline Q no & \multicolumn{1}{|c|}{ Question } & Mean & Rank \\
\hline 1 & Changes in Weather & 3.925 & 5 \\
\hline 2 & $\begin{array}{l}\text { Effect of wind } \\
\text { prevailing in the } \\
\text { construction site }\end{array}$ & 4.075 & 4 \\
\hline 3 & Unexpected rainfall & 4.225 & 1 \\
\hline 4 & $\begin{array}{l}\text { Change in the level } \\
\text { of water table due } \\
\text { to unexpected rainfall }\end{array}$ & 3.875 & 6 \\
\hline 5 & Water scarcity & 4.125 & 3 \\
\hline 6 & $\begin{array}{l}\text { Changes in the } \\
\text { monsoon cycle }\end{array}$ & 4.150 & 2 \\
\hline 7 & Extreme heat & 3.70 & 7 \\
\hline
\end{tabular}

Table 4.6 are the results obtained from the analysis which falls under quality related risk.

Table 4.6 Input data of quality related risk

\begin{tabular}{|c|l|c|c|}
\hline Q no & \multicolumn{1}{|c|}{ Question } & Mean & Rank \\
\hline 1 & $\begin{array}{l}\text { Unrealistic time } \\
\text { assessment }\end{array}$ & 4.0 & 5 \\
\hline 2 & $\begin{array}{l}\text { Unrealistic cost } \\
\text { assessment }\end{array}$ & 3.95 & 8 \\
\hline 3 & $\begin{array}{l}\text { Material selection for } \\
\text { construction work }\end{array}$ & 4.27 & 1 \\
\hline
\end{tabular}

\begin{tabular}{|c|l|c|c|}
\hline 4 & $\begin{array}{l}\text { Material usage for the } \\
\text { construction work }\end{array}$ & 4 & 6 \\
\hline 5 & $\begin{array}{l}\text { Poor inspection } \\
\text { of the site }\end{array}$ & 4.13 & 2 \\
\hline 6 & Inadequate design & 4.1 & 4 \\
\hline 7 & Poor work execution & 4.12 & 3 \\
\hline 8 & $\begin{array}{l}\text { Report on non } \\
\text { to quality standards }\end{array}$ & 3.67 & 10 \\
\hline 9 & Inspection delay & 4 & 7 \\
\hline 10 & Rework & 3.93 & 9 \\
\hline
\end{tabular}

Table 4.7 are the results obtained from the analysis which falls under safety related risk

Table 4.7 Input data of safety related risk

\begin{tabular}{|c|c|c|c|}
\hline Q no & Question & Mean & Rank \\
\hline 1 & Accident & 4.25 & 3 \\
\hline 2 & improper lighting & 4.22 & 4 \\
\hline 3 & Improper Ventilation & 4.07 & 7 \\
\hline 4 & Noise pollution & 3.65 & \\
\hline 5 & $\begin{array}{l}\text { Carelessness of } \\
\text { the labours }\end{array}$ & 4.2 & 5 \\
\hline 6 & $\begin{array}{l}\text { Not following the } \\
\text { safety rules }\end{array}$ & 4.27 & 2 \\
\hline 7 & $\begin{array}{l}\text { Distraction of labours } \\
\text { among themselves }\end{array}$ & 4.02 & 9 \\
\hline 8 & $\begin{array}{l}\text { Performing multiple } \\
\text { work tasks }\end{array}$ & 4.07 & 8 \\
\hline 9 & $\begin{array}{l}\text { Not giving proper rest } \\
\text { to workers }\end{array}$ & 4.42 & 1 \\
\hline 10 & $\begin{array}{l}\text { Improper usage of } \\
\text { safety protection items }\end{array}$ & 4.15 & 6 \\
\hline
\end{tabular}

Table 4.8 are results obtained from the analysis which gives the overall mean and overall rank of all the questionnaire that is being fed into the SPSS software

Table 4.8 Input data of overall mean and overall rank

\begin{tabular}{|l|c|c|}
\hline \multicolumn{1}{|c|}{ Risk } & Overall mean & Overall rank \\
\hline Technical risk & 4.1505 & 1 \\
\hline Management risk & 4.0127 & 4 \\
\hline Financial risk & 3.970 & 6 \\
\hline Environmental risk & 4.0107 & 5 \\
\hline Quality related risk & 4.1075 & 3 \\
\hline Safety related risk & 4.136 & 2 \\
\hline
\end{tabular}

\section{RESULTS AND DISCUSSION}

Based on the analysis obtained from SPSS and the questionnaire survey we have found that the factors under technical risk have got the maximum mean and highest rank. Many respondents have given importance to technical risk. The factors affecting productivity based on technical risk 
affects the construction productivity to a greater extent. By proper checking and inspection of activities in the construction site these problems can be minimized to greater extent. Before the commencement of the construction project the factors that affect the productivity of that particular project should be analyzed by referring to the past records and by analyzing through software's like SPSS. An engineer should be appointed to check these thus improving construction productivity. Next comes the safety related risk, more importance should be given to safety. The people involved in the project should taught about safety and an engineer should be appointed to track thus improving productivity. Financial risk cannot be taken into consideration because companies are not telling the financial details fully as it affects the companies development.

Based on my survey the factors based on the technical and safety related risk affects the construction productivity. I am glad to tell that we are working to develop a schedule on MS Project which improves productivity to a greater extent.

\section{Acknowledgements}

First and foremost I thank the Almighty, who has given me the strength to complete this task. Thereafter I would like to express my sincere gratitude and appreciation to the generosity of the following people who contributed to the success of this study.

- My guide, Professor.S.Anandh for his continuous professional guidance in keeping me focused on the research topic, for his on-going support and motivation throughout the study.

- I thank my brother Joshua, my parents, family members and friends for their support and encouragement.

- I thank all the engineers and contractors for filling up my questionnaire paper inspite of their busy schedule.

\section{REFERENCES}

[1] Abdullah, M.O. and Battaineh, H.T. (2002). Causes of construction delays: traditional contracts, Journal of Project Management, 20, 6773

[2] AbdulKadir, M., Lee, W., Jaafar, M., Sapuan, S., and Ali, A. (2005). "Factors affecting construction labor productivity for Malaysian residential projects." Structural Survey, 23(1), 42-54

[3] Adrian, J.J. 1987. Construction Productivity Improvement. New York: Elsevier.

[4] Analysis of Construction Fatalities (1990). The OSHA Data Base 1985-1989. United States. Arboleda, C. A. \& Abraham, D. M. (2004). Fatalities in trenching operations Analysis using models of accident causation. Journal of Construction Engineering and ManagementAsce, 130, 273280

[5] Abd El-Razek, M.E., Bassioni, H.A., \& Mobarak, A.M. (2008). Causes of delays in building construction projects in Egypt. Journal of Construction Engineering and Management, 134 (11), 831-841.
[6] El-Rayes, K. and Mosehli, O. (2001) Impact of rainfall on the productivity of highway construction. Journal of Construction Engineering and Management, 127(2), 125131

[7] Shehata, M. and El-Gohary, K. (2011). "Towards improving construction labor productivity and projects' performance." Alexandria Engineering Journal, 50(4), 321330.

[8] Assaf, S. A., Al-Khalil, M., \& Al-Hazmi, M. (1995). Causes of delay in large building construction projects. Journal of Engineering and Management, 17(2), 45-50.

Borcherding

[9] Kumaraswamy, M.M. and Chan, W.M. (1998). Contributes to Construction Delays, Journal of Construction Management \& Economics, 16; 1729. Lock, D.

[11] Okpala, D.C. and Aniekwu, A.N. (1988). Cause of high cost of construction in Nigeria .Journal of Construction Engineering and Management, ASCE, 114 (2) 223-34.

[12] Cleland, D.I. (1999). Project management strategic design and implementation, 3rd Ed., New York

\section{BIOGRAPHIES}

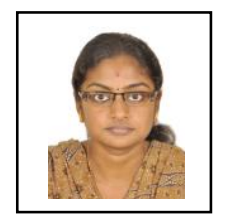

Indulekha.N , PG Student

Department of Civil Engineering,

SRM University, Katangulathur,

Chennai

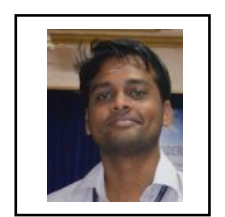

Anandh.S , Assistant Professor, Department of Civil Engineering, SRM University, Katangulathur, Chennai 